\author{
The Example of Hagop Ekizian's Migration From The Ottoman \\ Empire to America ${ }^{1}$ \\ Dr.Öğr.Üy. Mehmet Biçici \\ Gaziantep Üniversitesi, Fen-Edebiyat Fakültesi, Tarih Bölümü, Türkiye \\ Cumhuriyeti Tarihi Anabilim Dal, \\ bicici@gantep.edu.tr
}

\begin{abstract}
Armenians entered under the rule of Seljuks and then the Ottoman Empire after the Turks gained dominance in Anatolia. Armenians lived in an environment of tolerance and justice under the rule of Turks. There are scarcely any difference between the Armenians and Turks apart from religion. They had quite an interaction and close relationships which built an environment of trust between the Turkish and Armenians. However, Armenians started to rebel where they lived in the late 19th century as a result of the weakening of Ottoman Empire, oriental policy of the Western states and most accordingly their seditious acts towards minorities, specifically Armenians. In the 1820s, American missioners came to Ottoman lands and wanted to spread Protestantism by being especially active in the fields of education and health. The Ottoman Empire recognized the Protestant Armenian Community in the mid-19th century. During the migration of Armenians, who were subjects of Ottoman Empire, to the US, missioners nearly prepared the migration infrastructure with their activities in the Ottoman Empire. Some of the Armenian citizens migrated to the US and acquired American citizenship. This was due to the rights that arose from the 1830 American-Turkish Treaty of Commerce and Navigation. According to the treaty, those that became US citizens could not be judged by the Ottoman courts and were exempt from Ottoman taxes. Armenians even used that treaty as a protective shield in the rebels they started. Hagop Ekizian, a rich Armenian merchant and an Ottoman subject, also acquired American citizenship and took advantage of these privileges. The problem of nationality led to distress between the Ottoman Empire and the US who assumed a protective attitude against the crimes committed by the Armenians.
\end{abstract}

Keywords: Migration, Armenian, The US, Hagop Ekizian, Ottoman, Citizen.

\footnotetext{
${ }^{1}$ Makale Geliş/Kabul Tarihi: 10.10.18/05.03.18
} 


\section{Osmanlı Devletinden Amerikaya Ermeni Göçünde Agob İkizyan Örneği}

\section{Özet}

Türklerin Anadolu hâkimiyetini sağlamasından sonra Ermeniler önce Selçukluların daha sonra da Osmanlı Devleti'nin hâkimiyeti altına girmiştir. Ermeniler Türklerin hâkimiyeti altında hoşgörü ve adalet ortamında yaşamıştır. Ermeniler ile Türkler aradaki din fark1 olmasa birbirinden fark1 yok denecek gibidir. Birbirleriyle etkileşimleri ve yakın münasebetleri olmuştur. $\mathrm{Bu}$ durum Türkler ve Ermeniler arasında bir güven ortamı tesis etmiştir. Fakat Osmanlı Devleti'nin zayıflaması, batılı devletlerin şark politikası ve bunun sonucu olarak azınlıkları özellikle de Ermenileri isyana teşvik etmeleri ile XIX. yüzyılın sonlarına doğru Ermeniler yaşadıkları yerlerde isyan etmeye başlamıştır. 1820'lerde Osmanlı topraklarına gelen Amerikalı misyonerler özellikle eğitim ve sağlık alanında aktif olup Protestanlık Mezhebi'ni yaymak istemiştir. Osmanlı Devleti XIX. yüzyıl ortalarında Protestan Ermeni Milleti'ni tanımıştır. Osmanlı Devleti tebaası olan Ermenilerin Amerika'ya göçünde misyonerler Osmanlı Devleti'ndeki faaliyetleriyle bunun adeta alt yapısını hazırlamıştır. Ermeni vatandaşlardan bir kısmı Amerika'ya göç ederek Amerikan vatandaşlığını almıştır. Bunun nedeni ise 1830 Amerikan-Türk Ticaret Antlaşması'ndan doğan haklardır. Bu antlaşmaya göre Amerikan vatandaşı olanlar Osmanlı mahkemelerinde yargilanamıor ve vergiden muaf oluyordu. Hatta Ermeniler çıkardıkları isyanlarda da bu antlaşmayı bir koruma kalkanı olarak kullanıyordu. Zengin bir tüccar olan Agob İkizyan adlı Ermeni de Osmanlı tebaasından Amerikan vatandaşlığına geçerek bu imtiyazlardan yararlanma yoluna gitmiştir. Ermenilerin işledikleri suçlar karşısında himayeci bir tavır takınan Amerika ile Osmanlı Devleti arasında tabiyet sorunu gerginliklere neden olmuştur.

Anahtar Kelimeler: Göç, Ermeni, Amerika, Agob İkizyan, Osmanlı, Vatandaş.

\section{INTRODUCTION}

As one of the inhabitants of Anatolia, Armenians entered under the rule of various powers throughout history. After entering under the rule of Turks, they lived in an environment of peace and tranquility and, over time, became one of the most important classes of Ottoman Empire especially in trade. This continued until the 19th century and started to change especially after the arrival of American missioners to Anatolia. The process continued with disturbances and rebels until the Relocation and Resettlement Law in 1915. In such a distressed period, Armenians living in Anatolia migrated to the US which, at the time, they saw as attractive lands.

While it is not possible to mention a serious Armenian presence in the US in the second half of 18th century, their number increased rapidly as a result of the 
events that occurred in the last quarter of that century and the beginning of 19th century. Such that the number of Armenians that have migrated to the US reached about 50,000 by 1915 (İpek,1995,p.263-264).

Migration is a phenomenon that has been ongoing throughout human history. There are various reasons such as economical, social, political and cultural factors among the reasons for people's migration from where they live (Koçak,2012,p.164). The movement of migration can be internal or external (Şahin,2001,p.59). Furthermore, it is possible to classify migration as individual, mass, temporary, permanent, free and forced migration. This study will be discussing external migration, from the Ottoman Empire to the US. Migration from the Ottoman Empire to the US was individual, permanent and free migration with political and economical causes (İpek,1995,p.259).

It is possible to classify the Armenians that migrate to the US into 3 groups. The first group were few in number and consisted of Armenians that went to the US for educational purposes due to missioner's activities who arrived to Anatolia at the beginning of 18th century. The second group was the migration of merchants which increased especially towards the end of century. They were people that especially wanted to benefit from the provisions of TurkishAmerican Treaty of Commerce and Navigation signed in 1830. Due to the provisions of treaty, the US citizens could not be judged in Turkish courts. People that went to the US for this purpose were looking for ways to return back to Turkey as soon as they acquired their citizenship. The Ottoman Empire even started to take various precautions to prevent this from occurring. The third group, on the other hand, consisted of Armenians that migrated as a result of the Armenian insurgences and rebels. These people were rich merchants that were "disconcerted as a result of the unsuccessful revolts which emerged especially at the end of the century", and were also fugitive resistance movement members that were sought after by the government (İpek,1995,p.259-261).

During the Armenian revolts that intensified towards the end of 18th century, the port of Samsun played an important role in enabling connection with the Armenians. The benefit for those that lived especially in the inner regions, and there was quite a significant Armenian population surrounding the port. According to the census records of those years, 22,000 Armenians lived in the district of Trabzon whereas there were about 18,000 Armenians in the district of Canik around 1,200 of which lived in the township of Samsun (İskender,2006,p:104).

Together with the increased Armenian migration to the US, the Armenians that had spread to various parts of Anatolia looked for ways to migrate to the US. Armenians in and around Samsun used various means to migrate to such 
attractive lands. One of the most remarkable ones among these Armenians was Hagop Ekizian, a wealthy merchant. Hagop Ekizian asked for permission from the Ottoman Government to migrate to the US with his wife, and obtained the required permission to go to the US as a result of long bureaucratic processes. He returned back to the Ottoman lands after staying in the US for 5 years. In our study, the aim was to shed light on the political, diplomatic and social developments of the times by revealing the bureaucratic obstacles faced by Hagop Ekizian in regards to the archive documents.

\section{ARMENIANS IN THE OTTOMAN SOCIETY}

Being one of the inhabitants of Anatolia, Armenians called themselves Hay or Hayk, and the location they lived in Haylstan (Çayc1,2000,p:3). The name Armenia is found in the history of Herodotus, and inscriptions of Dorius (518 BC). The term Armenian or Armenia that is found in this document and other documents was used for the related location before the Armenian society that is called Armenian by the Turks and foreigners arrived there, and it was aimed to express the society of a specific geography rather than a certain ethnic group or society. The Armenian geography expressed as a geographical name can be defined as the place surrounded by the Euphrates in the west, Caucasus Mountains in the north, Azerbaijan and Iran in the east, and Mesopotamia in the south from the ancient ages by the 11th century. It would be correct to say that ancestors of today's Armenians were composed of the communities that settled in the area between 6th and 5th century BC. While it is not possible to discuss a country that can be named and described as Armenia with specific borders, it is not either possible to say that the community named as Armenians refers to the oldest inhabitants of the area (Cöhce,2014,p:1-2;Ercan,2001,p:76). There are different opinions about the origin of Armenians and they most probably they came to Anatolia from the Thrace (Balkan peninsula) towards the end of the 6th century BC, then settled and continued to live in the state of Urartu (Ilter,2003,p:7-8;Çayc1,2000,p:3;Ercan,2001,p:78).

In $300 \mathrm{AD}$, Armenians converted to Christianity and adopted the Gregorian belief. Armenians became the members of same religion with Byzantines when they converted to Christianity. However, Byzantines had conflicts with Armenians since they were members of the Orthodox Church. Byzantines also put a strain on Armenians in terms of religion (Gümüş,2014,p:219; Çayc1,2000,p:5).

Throughout the history, Armenians lived under the rule of Persians, Romans, Arabs, Byzantines, Seljuks, Safavids, Ottomans and Russians (Tezcan,2014,p:149-150;İskender,2006,p:99). Political conflicts between Rome 
and Armenians increased, starting from the reign of Armenian King Tigranes II. and the Battle of Tigranocerta broke out between the Armenians and Rome in 69 BC. Having being defeated in this war, the Armenians lost their freedom and entered under the rule of Rome and Parthia at times (Demir,2014,p:55). The first encounter of Armenians with Arabs and entrance under the rule of Arabs which occurred in the Battle of al-Qādisiyyah (636-637) during the reign of prophet Umar. Umayyads and Abbasids tried to gain dominance in the region where the Armenians resided, and subsequently witnessed fights between the Byzantines and Arabs (Gümüş,2014,p.209-218). While Armenians were under the rule of Byzantine Empire, they were subject to slaughters and exiles by the Greeks. Furthermore, heavy taxes, and Greeks' oppression on religious life and thoughts gave no respite to Armenians or to even let them think. Byzantine Emperor Heraclius (610-641) exiled the Armenian commanders and leading administrators to North Africa, while applying unbelievable tortures on them. Having been depressed by the Byzantine pressure, Armenians allied with Muslims under the guidance of Theodoros Rštuni, the General Commander of Armenia, and the reign of prophet Uthman (653). Thus the Muslim-Armenian alliance was established. Having been informed about such alliance, Byzantine Emperor Constans II advanced upon Armenia with an army of 100,000 soldiers. After arriving to Tercan, Constans II exiled 800 Armenian families that were settled in Tercan and its surroundings including women, children and the elderly to North Africa (654). The Greeks wanted to gain control of the Ani region upon the death of Ani King Ohannes (1041-1042). The Armenians that resisted the Greeks were tyrannized. What was told by the Armenian Historian Aristakaes de Lastivert is as follows: "Byzantine Armies invaded our cities, and carried out four attacks and plunders on Armenia. They killed or captured people by attacking with Fire and Iron. All cities almost turned into an empty desert. I get a lump in my throat, my mind stops working and I begin to shiver whenever I remember that pain. I cannot hold my pen to write these incidents, because what I am telling is full of sorrow and longing. Therefore, it is worthy if dry roads are wetted with my tears" (İpek,2003,p.31-38).

Byzantine Empire followed a severe imperialist and expansion policy even under the reign of Basil II and tried to annex the Armenian lands. Basil II arrived at Eastern Anatolia for this purpose and seized Vaspurakan. He forced the Armenians that lived there to migrate to Middle Anatolian regions such as Sivas, Kayseri, as well as Urfa. The Byzantine Empire thus carried out the greatest deportation in history (Kürkçüoğlu,2014,p.93-94). Mateos, the Great Armenian Historian from Urfa who lived in the 12th century describes in his Chronicles the oppression applied by Byzantines on Armenian in terms of religion as follows: "The emperor and his allies wanted to eliminate the Armenian Church and disrupt their belief in St. Gregoire Lusavoriç. They 
decided to remove the long-established and deep-rooted Armenian Church and replace it with their own demonic and complex church. Emperor Dugidz sent a message to the district of Sivas, and invited Armenian Princes Atom and Apushal to Istanbul. They went to Istanbul despite their suspicions on the intention of emperor. Emperor first met the due honor but later revealed his bad intentions and said: 'By virtue of the commands of our empire, you and all Armenian chairmen must be baptized in accordance with the Byzantine Church." (K1lı̧,2003,p.46-47).

We can say that the starting point of Turkish-Armenian relations refers to the time when Boğa el-kebir et-Türkî, one of the Turkish commanders in the Abbasid army, took total control of the Eastern Anatolia (851-852) (Göyünç,2002,p.233). Then the Seljuks, who marched until Anatolia with the establishment of Great Seljuk Empire in Khorasan in 1040 and the expansion of the state's borders after the raids made towards the west, started to settle in this region (Merçil,2011,p.47-49). As mentioned above, the presence of Armenians were at risk before the Seljuk rule in Anatolia due to massacre, exile, Orthodoxization and Hellenization policy of the Byzantines. Starting from 1071 especially, the Armenians that entered under the rule of Turks led a free life with peace and safety thanks to the fair and tolerant administration (İpek,2003,p.257).

During the Byzantine Empire period, Anatolian lands were in the hands of feudalism. Christians were serfs and the Seljuks converted the land into legal property, nationalized it, and distributed it to the Christian peasants thereby making them land owners. Thus, it brought down feudalism. The life and assets of non-Muslims were also assured and started to be protected by the state. For instance, it is seen in the literature that Italian merchants had a consulate in Sivas and resided in a church in Kemaluddin Inn. Another instance is that Latin merchants and Franciscans had churches in Erzincan and Erzurum, respectively. The Seljuks left the religion, language, customs and traditions of the inhabitants to their conquered regions and rather enabled them to be free in their way of life. The Armenian churches that Byzantine Empire tried to demolish were protected in Seljuk period. The heavy taxes levied on the Armenian church, monasteries and clergy by the Byzantines were removed, and they were exempted from taxes in Seljuk period. The Armenians were never forced to be Muslims, and were let free in their religious services and education. According to the literature, Ani Armenian Archbishop Barseğ went to Sultan Malik-Shah in İsfahan in 1091 to present the state of Armenian Patriarchate. Malik-Shah not only welcomed the committee very warmly, but also prepared a decree and submitted it to Barseğ which stated that Armenian Patriarchate was going to be 
represented by a single authority only and all the churches, monasteries and clergy would be exempt from taxes (Türkmen,2014,p.129-141).

Mateos, the Great Armenian Historian from Urfa, tells about the Antakya Expedition (1086) of Sultan Malik-Shah and the state when he was heading for Baghdad: "Heart of the Sultan was full of compassion for Christians. He was seeing the people of the regions he was passing by through the eyes of a father. Thus he conquered several states and districts without having to battle" (Ersan,2014,p.169). Seljuk sultans were married to non-Muslim women as well. Georgians, Armenians and Greek were among these women. Seljuk sultans did not get involved in religious beliefs or services of the non-Muslim women when married. Marriages were not limited with the Seljuk dynasty, and also occurred between the Turkish men and non-Muslim women of equal status (Türkmen,2014,p.142-143).

Ottomans approached the Armenians that entered under the rule of Ottomans after the Seljuk period with tolerance as they did to all other non-Muslims. Ottomans were expanding their borders with the dispose policy. The main philosophy of the dispose policy was tolerance (Ortayl1,2002,p.217-218). NonMuslims that lived in the Ottoman Empire were called dhimmi. The lives, assets, honor and chastity of the dhimmis that recognized the rule of Ottoman Empire were protected and untouched by the state. In exchange, dhimmis paid taxes called jizya and gave tributes to the government. They were also asked to avoid acts that would break the peace, and to adhere to the laws (Şener,2014,p.116-117). Non-Muslims had beliefs, religious services and education rights in the Ottoman Empire and were not forced to convert their religion; they carried out their religious services freely and received education in the schools they opened. Pursuant to the nature of social state, the people that could not pay taxes were exempt from them. These people were women, children, elderly, people with insolvency, clergymen and those that were beneficial for the state. Non-Muslim men were exempt from military service since they paid a tax called jizya. In the Ottoman society, non-Muslims had the right to work, trade, travel, get married, and follow freely their own customs and traditions. Non-Muslims were given the opportunity to settle and continue their lives in the entire Ottoman region excluding Hejaz, where Islam was spread. The clothes of the dhimmis had to be different from the clothes of Muslims, which, in a way, prevented them from being assimilated. According to Islamic law, dhimmis could not be heads of the state. In Ottoman Empire, dhimmis were not assigned as head of the state, army commander, governor or judge but took office in bureaucracy (Bilgiç,2003,p.79-88).

We can see in the decrees and licenses given for non-Muslims that they are totally free in their religious services and rituals. A decree given for the Galata 
community by Fatih is an example: "And even I have accepted that they should carry out their rituals, customs and rules the way they have always done." Similar documents were renewed by each sultan (Şeker,2014,p.160). As mentioned above, Armenians that were members of the non-Muslim community and lived under the rule of Ottoman Empire were the second most populous nation in the Ottoman Empire after the Greeks (Özcan,2014,p.132). After Mehmed II conquered Istanbul, in 1461 he brought the Armenian Bishop Yovakim who was in Bursa to Istanbul and conferred him the title of Armenian Patriarch (Kuran,2001,p.39;Göyünç,2002,p.234-235). Thus Armenians gained the opportunity to arrange their education, religion, foundation and family works in accordance with their own customs under the supervision of patriarch (Çayc1,2000,p.11). All regions where Armenians were a part of the Christian class lived for hundreds of years in the Ottoman Empire (Halaçoğlu,2002,p.482). and entered the rule of Ottomans in the middle 16th century (Çayc1,2000,p.12). The Rayah that was administered in the Ottoman Empire relied upon the nationality system. While the term nationality does not express the ethnic and linguistic belonging, it is based on the religious and sectarian belonging. Accordingly, Armenians were divided into 3 nationalities as Gregorian-Armenian, Catholic-Armenian and Protestant-Armenian (Ortayl1,2002,p.218). However, Armenians lived (Kazıc1,2002,p.221-224) and mixed with Turks for centuries in an environment of tolerance, justice and freedom. Such that German Captain Helmuth Von who arrived in Turkey in 1835 talks about Armenians as follows: "It is possible to call Armenians Christians Turks actually. They took so much from the ruling nation's justice and even language. Since they are Christians, their religion allows them to have one woman. But that woman stays completely away from eyes almost like Turkish women. When Armenian women walk on the street, only the eyes and upper part of their noses can be seen." He also talks about Armenian food as below: "Food culture is totally related to Turkish style lamb and rice meals and most of the meals include desserts" (Göyünç,2002,p.239). An example of a Turkish and Armenian mosaic was described by the Italian writer Edmondo De Amicis while he was in Istanbul at the last quarter of the 19th century which can be seen below: By saying "Christian by spirituality and religion, and Asian Muslim by birth and materialism", he implies that Armenian and Turkish cannot be separated at first look (Kazıc1,2002,p.231). According to İlber Ortayl1, Armenian and Turkish had deep cultural interaction and vicinity because they lived together for centuries. He says if there was not a cross and crescent which refer to a religious difference, these two culture could not be separated (Ortayl1,2014,p.193).

Armenians used Turkish as their native language. Turkish texts with Armenian letters appeared after the 16th century. Between 1727 and 1918, there 
were 900 Turkish books with Armenian letters (Koloğlu,2002,p.511). Turkish literature and musicals had an impact on Armenians too; several Armenian composers were raised. There was also an interaction between the Armenians and Turks in stage arts (Göyünç,2002,p.241-244). Armenians embraced Turkish cuisine, and cooked Turkish food in their kitchen (Çayc1,2000,p.14). In architecture, some Armenians served for the Ottoman state too. The most famous Armenian was from Balyan family in the 19th century; the architecture of Dolmabahçe Palace and many similar buildings belonged to them (Yağc1,2014,p.100-101).

The Armenians who resided in villages had lands. Those who lived in cities were engaged in professions such as trade, artisanship, money changing, banking, construction and medicine. Armenians started to be assigned to foreign ministry and other ministries, embassies, undersecretaries, and supervisorships after the Declaration of 1839 Edict of Gülhane and 1856 Imperial Reform Edict. The regulation named "Nizâmnâme-i Millet-i Ermeniyân" (The Armenian National Constitution) published on March 29, 1863 virtually provided the Armenian people with independence. With this regulation, Armenians had access to their own parliament for solving their own social, religious and cultural problems (Çayc1,2000,p.14-17).

\section{ARMENIANS THAT MIGRATED TO THE U.S.}

Migration has always been a part of human history. There are different reasons for these migrations as well as various types; people migrated in individual, mass, temporary, forced or permanent forms. Migration from the Ottoman Empire to the US was individual, free and permanent which arose from political, economic and educational reasons (Ípek,2003,p.259). It is also evident that external factors had an effect on these migrations. The Edict of Gülhane signed in 1839 and the Imperial Reform Edict signed in 1856 mobilized the minorities in the 19th century (İskender,2006,p.101-102). The Armenian problem emerged because the Ottoman Empire signed the Treaty of San Stefano and Treaty of Berlin at the end of the battle with Russia between 1877 and 1878 and there were provisions regarding reforms to be made at the places where Armenians resided. In actuality, this was a result of the oriental policy of Western states. As a consequence, Armenians were provoked and bloody incidents took place (Karagöz,1998,p.252). In this regard, effect of America on Armenians took place via the missioners. The missioners had a role in the rebels of Armenians. These missioners not only served the policy of America but also became a factor in the disruption of Turkish and Armenian relations (Akgün,1988,p.1).

The missioners that arrived at Ottoman lands in 1820 contacted the Armenians in 1830s. The first missioners were Plinky Fisk and Levi Parsons. 
American merchants, diplomats and consuls must also be noted along with these missioners (İskender,2006,p.109). Gregorian Armenian Church developed an attitude towards the missioners that wanted to spread Protestantism, and excommunicated the Armenians that converted to Protestantism. The Ottoman Empire, on the other hand, did not object to the activities of America on its own lands, which it believed was neutral and non-imperialist, and also recognized the Protestantism Church, which was tried to be spread by missioners, as a nationality in 1848. This eliminated the challenges faced by the American missioners in their missionary activities while opening schools or churches, as well as buying lands and constructing buildings for these activities. Missioners firstly established primary schools in several locations of the Ottoman Empire. Armenians that sent their children to these schools later wanted their daughters to be educated in such schools as well. It can be found in literature that 10,000 Armenians in Antep made a written application to get their daughters educated in these schools. In a short time, missioners that spread to several parts of Anatolia established 7 Protestant churches whose number of members exceeded 268 between 1831 and 1850 .

The first missioner center was founded in Izmir in 1820. Afterwards, missioner centers were opened in Beirut in 1823, Istanbul in 1831, Trabzon in 1835, Erzurum in 1839, Antep in 1847, Sivas in 1851, Adana and Merzifon in 1852, Harput in 1855, Tarsus in 1859 and Van in 1872 (Akgün,1988,p.4-7). After 1830, an educational campaign was started by the American missioners amongst the Armenians which continued to increase. This education was also provided for military purposes by the Armenian committees in the US, and illustrated books instructing the military drills were published and given to Armenians. Medals and coat of arms were also prepared for the Armenians that received military training (İskender,2006,p.109).

The second most commonly used mission by the American missioners after their educational missionary activities were activities in the healthcare field. Because one of the means to reach people was the treatment of diseases. Thus, the activities of missioners in healthcare fields were ChristianizationProtestantization of the people. For this purpose, missioners opened hospitals that provided training in the fields of medicine, pharmacy, dentistry and nursing. Ottoman Empire's failure to open sufficient number of schools that provide health training in Anatolia as well as its distant attitude towards modern treatment gave the missioners opportunity to open health institutions in Anatolia.

The first missioner physician that came to Ottoman Empire was Dr. Asa Dodge. Then doctor missioners such as Dr. Cornelius Von Dyke, Dr. Azarioh Smith, Dr. Asakel Grant, Dr. Henry Lobdell, Dr. George E. Past arrived at 
Anatolia. American missioners opened hospitals in locations such as Antep, Kayseri, Mardin, Van, Istanbul, Amasya, Sivas, Harput, Diyarbakır, Konya and Erzurum. Armenians that received their education in the schools of missioners eventually worked in the hospitals and dispensaries that they opened. American Red Cross was also active in Anatolia in the field of healthcare. The most important reason for American Red Cross to come to Anatolia was the rebel started by Armenian commissioners in Zeytun and Maraş in 1895. American Red Cross helped the Armenians in the fields of healthcare, agriculture, agricultural instruments and technical issues. It supported Armenians in locations such as Antep, Urfa, Maraş, Harput, Samsun, Tokat, Sivas, Malatya, Diyarbakır, Silvan and Kemaliye. American newspaper, 'The New York Times', not only made the Armenian revolts look like innocent but also wrote that no-one except the missioners sent aid to the region. The revolts and massacre carried out by the Armenians were described unfairly in the American press, and Turks were cursed and defamed in churches (Kuzgun,2015,p.515522). Armenian revolts and terrorism activities started in 1890 s and continued until 1914 (Çayc1,2000,p.34). Ottoman Empire noticed that American missioners opened establishments and increased their activities in the locations where Armenians resided. It reported to Anatolian districts that these establishments carried out activities in favor of Armenians, distributed guns and harmful documents to Armenians and encouraged them to rebel. In an orphanage opened by the American missioners in Hacin (Saimbeyli), Armenian children were forcefully taken and subjected to Protestantism propaganda. Ottoman Empire tried to take precautions in return (Kuzgun,2015,p.514). American missioners also established close relations with Armenians that were engaged in trade; and thus they tried to constitute an Americanized Armenian society.

The protection of the Armenians was enabled thanks to the institutions opened by the US in the Ottoman Empire (Kuzgun,2015,p.513). American merchants, on the other hand, benefitted from the Armenian brokers when sending the goods they brought to inner Anatolia. While the Armenian merchants engaged in activities that provoked Armenians, Armenians in Istanbul and Anatolia started to acquire American citizenship. The greatest reason for the Armenians to acquire American citizenship was the TurkishAmerican Treaty of Commerce and Navigation signed in 1830. An article found in this treaty was as follows: "American citizens cannot be judged in Turkish courts." Armenians that were American citizens and benefitted from this provision of the treaty rebelled and engaged in terrorist actions (Akter,2007,p.15; İskender,2006,p.109). 
The Armenian migration from the Ottoman Empire to the US continued increasingly as from the second half of 19th century. In 1890s, Armenians rebels that started in Anatolia failed. Wealthy merchants, revolutionary association members and intellectuals that could not receive the support of Armenian society migrated to Iran, Egypt, Europe and especially America (İpek,2003,p.260-261). After the declaration of Second Constitutionalist Era, military service became obligatory for non-Muslim subjects; America was one of the countries where non-Muslims that did not want to do military services migrated to (Kara,2012,p.173-174). Armenians also migrated for their safety as Armenian organizations tortured their own people and forcefully asked for money in order to achieve their purpose; these organizations even killed their own people. Here are some examples: Priest Mampre, Lawyer Haçik, Lawyer Sebah, Merchant Apik Uncuyan, and Merchant Balyozyan and many other people were killed in Üsküdar, Topkap1, Galata, Galata and İzmir, respectively (Akter,2007,p.48).

The demand of large states for workforce also accelerated the migration of Armenians from the Ottoman Empire. Some Armenians that were citizens of the Ottoman Empire encouraged the Armenians to migrate to the US and carried out human trafficking activities. Human trafficking was performed between Sivas and Worchester by associations which were established to encourage Armenians to migrate to the US, and then subjected to investigation. The association established by Gaspar Nahicyan in Harput was an example, which also had a branch in Istanbul. The Armenian Relief Committee made an application for the mass migration of Armenians (Bayraktar,2015,p.511-512). Publications made by the Western and Armenian press which would create discontent such as continuous fear and massacre also triggered the Armenian migration. The Armenian newspaper Haik encouraged Armenians to migrate, and Ayazdan from London published articles against the Ottomans and Troth was also among these newspapers (Bayraktar,2015,p.514-515).

As a result of the activities of American missioners in the Ottoman Empire, Armenian youth, handicraftsmen, artists and peasants migrated to the US (İpek,2003,p.262). The most populous non-Muslim society that migrated from the Ottoman Empire to the US was the Armenians (Kara,2012,p.175). Young Armenians started to migrate to the US for educational purposes starting from 1840 as a result of the educational activities performed by American missioners on the Ottoman lands. Some of the Armenians that migrated, settled in America while others took the American passport and returned back to Anatolia. Those that received theology education were serving as priests in the Protestant churches which enabled missionary activities to continue in Anatolia. The ones that received technical education worked in different jobs 
(İpek,2003,p.260;Kara,2012,p.176). There were also Armenian merchants that migrated to the US. Craftsmen, artisans and peasants migrated to the US in 1890s. The development of South America in agriculture and North America in industry increased the need for manpower (İpek,2003,p.260). Because there were droughts, epidemics, a grasshopper invasion, and long-lasting wars in the Ottoman Empire in this period (Bayraktar,2015,p.505). These became compelling reasons in the migration of Armenians to the US. The Ottoman Empire banned migration of Armenians to the US due not to wanting to lose its population and tax income, and poor migrants not to harm the Ottoman prestige, and with the concern that Armenians would return with American passport. Apart from that, there was a request for establishing a commission to investigate the migration reasons of Armenians; but when it was 1915, number of Armenians that migrated to the US had reached nearly 50,000 (İpek,2003,p.262-264).

\section{BIOGRAPHICAL INFORMATION ABOUT HAGOP EKIZIAN}

Armenians in and around Samsun used various means to migrate to such attractive lands. One of the most remarkable ones among these Armenians was Hagop Ekizian, a wealthy merchant. Hagop Ekizian wanted to migrate to the US with his wife from Samsun, and the permission was given as a result of long bureaucratic processes. The fact that the US embassy bestowed a privilege upon Ottoman Empire for the Armenians to migrate to the US can be found in literature as in the Hagop Ekizian example. People that wanted to migrate from the Ottoman Empire were not allowed to return back to the Ottoman lands. Ottoman Empire permitted migration provided that this was proven with guarantor and certified bills and approved by the Patriarchate and authorized departments, and the person's all connection was severed with the state with photos on the required documents (BOA,A.MKT.MHM.542/28/1). However, Hagop Ekizian returned back to the Ottoman Empire 5 years after he migrated (BOA, A.MKT. MHM.542/28/7). The hometown of Hagop Ekizian is stated in sources to be Harput (BOA,A.MKT.MHM.542/28/4). But he went to many parts of the Ottoman Empire since he was a merchant. While Hagop Ekizian was a commissioner in Dersadet (May 18, 1314), he had 4 brothers named Ohans in Dersadet, Karabet in the US, Kifork in Samsun, and Girgor in Harput. They owned their properties and revenue (money making enterprises such as vineyard, farm, shop) all together. It is also sourced that these people owed about 7 or 8 thousand Lira to the craftsmen and community, and thus were subjected to police investigation. This debt issue even became one of the complicating reasons in the request of Hagop Ekizian to migrate to the US, and was investigated by the authorized departments (BOA,A.MKT. MHM.542/28/10,14,15). 
The Migration of Hagop Ekizian to the US and His Return, Practices in Anatolia During This Period and Ekizian's Utilization of Such Practices

According to the information we have gained from relevant sources, Hagop Ekizian tried to get permission to migrate to the US with his wife (BOA, A.MKT. MHM.542/28/16,3)and was willing to leave the nationality of Ottoman Empire by giving a bill to the Sublime Porte (İpek,2003,p.267). Hagop Ekizian went through long bureaucratic processes to migrate to America, and there were correspondences between both the US embassy and Sublime Porte, governorships of the districts and the authorized departments ( BOA,A.MKT. MHM.542/28/13,1,11). As we have mentioned above, Ottoman Empire prepared documents for the people who wanted to migrate and did not want them to return back to the Ottoman lands again (BOA,A.MKT. MHM.542/28/1). It is understood from the documents that consulates opened by the US in the Ottoman Empire were effective in Armenians' migration to the US, and also spent efforts to accelerate the works during migration processes. For instance, the US consulate in Samsun got Hagop Ekizian and his wife in an American-flagged boat, took them to a ship and then returned back alone (BOA, A.MKT. MHM.542/28/16). According to the information obtained from sources, Hagop Ekizian returned back to the Ottoman Empire after his migration:

“Makam-ı Mualla-yı Sadaret Uzemaya

Fi 16 Mart 1314'te Agob Ikkizyan Harput şehri ahalisinden olup geçende Samsun' a gelerek Amerika tabiyeti iddiasinda bulunmuş ve bir de pasaport ibraz etmiş ise de 2 buçuk sene evvel Amerika'dan avdet eylediği halde pasaportunda işaret görülemediği için MamüretülazizVilayeti'nden bilistifsar alinan cevapta merkumun 10 sene evvel Amerika'ya azimet ve 5 sene sonra avdet ettiği ve memleketince hakkinda Teba-i Osmaniye muamelesi icra ve tekâlif-i emriye istizar edildiği ve bu defa Samsun'a zevcesiyle azimet eylediği işar olunmasina göre Tabiyet-i Osmaniye'yi terk ile fima bat Memalik-i Şahaneye avdet etmeyeceğine dair olacak kat'l alaka muamelesinin memleketince icrası münasip görünmekle hemen avdetle muamele-i lâzımeyi mahallinde icra edeceğine dair kefil irae eylediğinin Canik Mutasarrıflı̆̆ı'ndan bildirildiği maruzdur.

Ferman Fi 19 Mart 1314

Trabzon Valisi Kadri" (BOA, A.MKT. MHM.542/28/7).

Like some Armenians, Hagop Ekizian returned back to the Ottoman Empire after acquiring his American citizenship and passport. As the Ottoman Empire signed the Turkish-American Treaty of Commerce and Navigation with America in 1830, American citizens could not be judged in Turkish courts. 
American citizens were also exempt from the taxes of Ottoman Empire. As a wealthy merchant, Hagop Ekizian also utilized this practice and similar ones (İskender,2006,p.109;Kara,2012,p.178;'̈pek,2003,p.264). Those that did not want to do military service and therefore Armenians also acquired American citizenship to be exempt from doing military service in the Ottoman Empire (Kara,2012,p.173;Akter,2007,p.27).

When the Ottoman Empire could not prevent its own subjects from changing their nationalities, it tried to take precautions considering that they would pose a problem in the future. One of these precautions was the "Code of Osmanieh Nationality" passed in 1869. Pursuant to this law, everyone that resided in the Ottoman Empire were considered Ottoman citizens. If a person was a foreigner, they had to prove it. Those that were expatriated or ceased to be a citizen with their own will were banned from returning back to the Ottoman Empire again. When those that were Ottoman subjects and fled without gaining permission became subjects of a foreign state and claimed that they belonged to a foreign nationality after returning back to the Ottoman lands, their claims would not be accepted and they would be considered and treated as subjects of Ottomans (Akter,2007,p.26). Since some of the Armenians that became American citizens returned back to Ottoman lands, the Ottoman Empire warned the nationality secretariat and ordered that American citizenship of the Armenians that returned back would not be recognized.

The Ottoman Empire wanted to prevent migration to the US. Armenians that acquired American citizenship and returned back to the Ottoman Empire were rebelling, threatening the security of state and getting engaged in subversive activities (İpek,2003,p.264-265). The Ottoman Ministry of Foreign Affairs contacted the foreign representation offices and wanted Armenian migration that was received from the Ottomans would not be accepted (İpek,2003,p.263). The nationality problem between the Ottoman Empire and America tried to be solved, and Nationality Conversion Agreement was signed in August 11, 1874. This agreement did not become effective when a controversy emerged among the articles. This agreement was then revised and signed by Arif Pasha, the Ottoman Empire Minister of Foreign Affairs, and George Boker, America's Istanbul ambassador. But signing of the agreement did not end the migration and nationality problems between the Ottoman Empire and the US (Akter,2007,p.26-29). When Armenians' arrival to Ottoman Empire was prevented by the Ottoman Empire, the US reflected this as the violation of capitulations. The New York Tribune newspaper's article on December 17, 1893 reported that Armenians with American passport were arrested when they arrived at Ottoman lands, and their judgement for the crimes that have committed must be carried out by the American counsels. The Ottoman Empire 
called the Armenians that got their registers deleted by giving bills to the government and left the Ottoman nationality consensual. They called fugitives to those that had no official processes carried out who just fled from the Ottoman Empire. Ottoman Empire laid down conditions for the people that wanted to return back to Ottoman Empire. Firstly, they had to prove that they left the nationality of a foreign country with official documents, and would not claim for foreign citizenship, otherwise, they were going to be deported (İpek,2003,p.266-267).

\section{CONCLUSION}

As a phenomenon, migration always occurred throughout history. Migrations can have the characteristics of being internal and external. We can list migrations caused mainly by social, economic, political and cultural reasons. Our study named 'The Example of Hagop Ekizian's migration from the Ottoman Empire to America" was addressed under the light offered by archival sources. Like some Armenians, the Armenian called Hagop Ekizian also acquired American citizenship when he was an Ottoman citizen. Migration of Armenians to America was by their own will. The Ottoman Empire did not want to lose its own population to migration abroad, because losses were observed in Ottoman Empire's population, tax, manpower, craftsmen, artists and various occupations when some Armenians migrated to the US and acquired American citizenship. Hagop Ekizian, who was an Armenian citizen of the Ottoman Empire, was a striking example of that. As a wealthy merchant, Hagop Ekizian and his wife acquired American citizenship, and became exempt from taxes and being judged at Ottoman courts. The hometown of Hagop Ekizian is stated to be Harput in sources. However, he went to many parts of the Ottoman Empire since he was a merchant, and while Hagop Ekizian was a commissioner in Dersadet, he had 4 brothers named Ohans in Dersadet, Karabet in the US, Kifork in Samsun, and Girgor in Harput. We have learned from the sources that these 5 brothers had common real estates and revenue, owed money to the craftsmen and community, which was investigated by the police and became one of the reasons that prevented the migration of Hagop Ekizian to the US.

The Armenians started to migrate to the US towards the end of 19th century. However, some Armenians not only acquired American citizenship but also returned back to the Ottoman lands and started rebelling. As the Ottoman Empire's efforts to prevent this, arrests and different precautions caused the relationship between America and Ottoman Empire to break down. Virtually 
Americanized Armenians as a result of the activities of American missioners in the Ottoman Empire caused the Ottoman Empire to be faced with various problems. Armenians that settled in the US established the Armenian lobby, made Ottoman opposition, supported the rebels that arose in Anatolia and provided financial assistance to the rebels.

Having arisen from the capitulations, American-Turkish Treaty of Commerce and Navigation signed in 1830 provided the opportunity for the US to get involved in the internal affairs of Ottoman Empire. It opposed the arrests of the US citizens by giving the treaty as justification, and wanted the criminals to be delivered to the US consulate. Migration issue troubled the Ottoman Empire for long years and disrupted the relations with the US.

Therefore, Armenian migrations from the Ottoman Empire to the US, and the Armenians' utilization of the concessions by returning back to the Ottoman lands as an American citizen confronted the Ottoman Empire with social, economic and legal challenges.

\section{References}

BOA, A.MKT. MHM.542/28/1; 3; 4; 7; 10;11; 13; 14; 15; 16.

AKTER, Ahmet, Tehcir Öncesi Anadolu'dan Amerika'ya Ermeni Göçü (1834-1915), IQ Kültür Sanat Yay., İstanbul 2007.

ÇAYCI, Abdurrahman, Türk-Ermeni İlişkilerinde Gerçekler, Atatürk Araştırma Merkezi, Ankara 2000.

MERÇİL, Erdoğan, Müslüman Türk Devletleri Tarihi, TTK. Yay., Ankara 2011.

AKGÜN, Seçil, "Amerikalı Misyonerlerin Ermeni Meselesinde Rolü" Ankara Üniversitesi Türk İnkılâp Tarihi Enstitüsü Atatürk Yolu Dergisi, Say1 1, 1988, ss.1-12.

BAYRAKTAR, Hilmi, "XIX. Yüzyılda Ermenilerin Osmanlı Devleti'ni Terkinde Yerli ve Yabancı Basının Etkisi Üzerine Düşünceler", 1920. Yüzyıllarda Türk-Ermeni İlişkileri Kaynaşma-Kırgınlık-AyrılıkYeni Arayışlar, (Ed: Fatih M. Sancaktar vd.), C.1, Uluslararası Sempozyum Bildiriler, İstanbul 2015, ss.503-518.

BİLGİÇ, Veysel K., “Osmanlı Devleti’nde Azınlıklar” Dünden Bugüne TürkErmeni İlişkileri, (Ed: İdris Bal vd.), Nobel Yay., Ankara 2003, ss.7790 . 
CÖHCE, Salim, "Ermenistan'ın Tarihi Coğrafyası ve Ermeniler", Tarihte Türkler ve Ermeniler (Illk ve Ortaçağ), (Ed: Mehmet Metin Hülagü vd.), TTK. Yay., C.1, Ankara 2014, ss.1-14.

DEMIR, Muzaffer, "Roma-Armenia İlişkileri (M.Ö.95-M.S.118)", Tarihte Türkler ve Ermeniler (ilkçağ ve Ortaçağ), (Ed: Mehmet Metin Hülagü vd.), TTK. Yay., C.1, Ankara 2014, ss.55-98.

ERCAN, Yavuz, “Ermeniler ve Ermeni Sorunu”, Osmanlı'dan Günümüze Ermeni Sorunu, (Ed: Hasan Celal Güzel), Yeni Türkiye Yay., Ankara 2001, ss.75-104.

ERSAN, Mehmet, "Türk-Ermeni İlişkileri (XI.-XIII. Yüzyıllar)", Tarihte Türkler ve Ermeniler (Ortaçağ), (Ed: Mehmet Metin Hülagü vd.), TTK. Yay., C.2, Ankara 2014, ss.161-202.

GÖYÜNÇ, Nejat, “Osmanlı İmparatorluğu'nda Ermeniler”, Türkler Ansiklopedisi, (Ed: Hasan Celal Güzel vd.), C.10, Ankara 2002, ss.233250.

GÜMÜŞ, Nebi "İslam Tarihi Kaynaklarında Ermeniler", Tarihte Türkler ve Ermeniler (İlkçağ ve Ortaçağ), (Ed: Mehmet Metin Hülagü vd.), TTK. Yay., C.1, Ankara 2014, ss.207-223.

HALAÇOĞLU, Yusuf, "Ermeni Tehciri ve Gerçekler", Türkler Ansiklopedisi, (Ed: Hasan Celal Güzel vd.), C.13, Ankara 2002, s.482582.

İLTER, Erdal, "Ermenistan Adı, Ermenilerin Menşei ve Türk-Ermeni İlişkileri Konusunda Tespitler”, Dünden Bugüne Türk-Ermeni İlişkileri (Ed: İdris Bal vd.), Nobel Yay. Ankara 2003, ss.3-10.

İPEK, Ali, "Ermenilere Rum Mezalimi”, Dünden Bugüne Türk-Ermeni İlişkileri, (Ed: İdris Bal vd.), Nobel Yay., Akara 2003, ss.31-38.

İPEK, Nedim, “Anadolu'danAmerika'ya Ermeni Göçï”, OTAM, Sayı.6, Ankara 1995, ss. 257-280.

İSKENDER, Pelin, "Berlin Antlaşması'ndan Sonra Samsun ve Çevresinde Ermeni Olayları", Geçmişten Geleceğe Samsun, Samsun Büyükşsehir Belediyesi, Samsun 2006, ss.99-114.

KARA, Adem, “Güney Amerika Kıtası'na Göç Eden Osmanlı Ermenileri”, International journal of Social Science, Volume 5 Issue 5, October 2012, 171-183. 
KARAGÖZ, Rıza, "Canik Sancağında Ermeni Çetelerinin Faaliyetleri (1894-1896)”, 19 Mayıs Üniversitesi Eğitim Fakültesi Dergisi, Samsun 1998, ss. 251-257.

KAZICI, Ziya, “Osmanlılar'da Hoşgörü”, Türkler Ansiklopedisi, (Ed: Hasan Celal Güzel vd.), C.10, Ankara 2002, ss.221-232.

KILIÇ, Davut, "Selçuklulara Kadar Anadolu'da Gregoryen Ermeni Kilisesi (M.451-1100)”, Dünden Bugüne Türk Ermeni İlişkileri, (Ed: İdris Bal vd.), Nobel Yay., Ankara 2003, ss.39-50.

KOÇAK, Yüksel, Elvan Terzi, "Türkiye'de Göç Olgusu Göç Edenlerin Kentlere Olan Etkileri ve Çözüm Önerileri”, Kafkas Üniversitesi İktisadi ve İdari Bilimler Fakültesi Dergisi, C.3, S.3, 2012, ss.163-184.

KOLOĞLU, Orhan, "Osmanlıdaki Türk Olmayan Cemaatlerde Türkçenin Yeri”, Türkler Ansiklopedisi, (Ed: Hasan Celal Güzel vd.), C.11, Ankara 2002, ss. 509-514.

KURAN, Ercüment, “Tarihte Türkler ve Ermeniler”, Osmanlıdan Günümüze Ermeni Sorunu, (Ed: Hasan Celal Güzel), Yeni Türkiye Yay., Ankara 2001, ss.39-46.

KUZGUN, Meral, Ebru Güher, "Amerikalı Misyonerlerin Anadolu'da Yardım Faaliyetleri Çerçevesinde Sağlık Misyonu”, International Periodical for the Languages, Litareture and History of Turkısh or Turkic Volume 10/9 Summer 2015, Ankara-Turkey, ss. 505-534.

KÜRKÇÜOĞLU, Erol, "X-XI. Yüzyıllarda Doğu Roma ve Selçukluların Ermenistan (Bagratuni-Ardzruni) Politikaları", Tarihte Türkler ve Ermeniler (Ortaçağ), (Ed: Mehmet Metin Hülagü vd.), TTK. Yay., C.2, Ankara 2014, ss.89-106.

ORTAYLI, İlber, “Osmanlı Devleti'nden Günümüze Ermeniler", Tarihte Türkler ve Ermeniler (Birlikte Yaşama Kültürü), (Ed: Mehmet Metin Hülagü vd.), TTK. Yay., C.3, Ankara 2014, ss.193-202.

ORTAYLI, İlber, “Osmanlı İmparatorluğu'nda Millet Sistemi”, Türkler Ansiklopedisi, (Ed: Hasan Celal Güzel vd.), C.10, Ankara 2002, ss.216220.

ÖZCAN, Besin, “Osmanlı Devleti ve Ermeni Teşekkürnameleri”, Tarihte Türkler ve Ermeniler (Birlikte Yaşama Kültürü), (Ed: Mehmet Metin Hülagü vd.), TTK. Yay., C.4, Ankara 2014, ss.127-147. 
ŞAHİN, Cengiz, "Yurt Dışı Göçün Bireyin Psikolojik Sağlığı Üzerindeki Etkisine İlişkin Kuramsal Bir İnceleme", G.Ü. Gazi Eğitim Fakültesi Dergisi, C.21, S.2, 2001, ss.57-67.

ŞEKER, Mehmet, "Selçuklular ve Osmanlılar Döneminde Ermeniler İle Bir Arada Yaşama Örneği”, Tarihte Türkler ve Ermeniler (Birlikte Yaşama Kültürü), (Ed: Mehmet Metin Hülagü vd.), TTK. Yay., C.3, Ankara 2014, ss.149-166.

ŞENER, Abdulkadir, “İslam Hukukunda Gayr-i Müslimler”, Tarihte Türkler ve Ermeniler, (Birlikte Yaşama Kültürü), (Ed: Mehmet Metin Hülagü vd.), TTK. Yay., C.3, Ankara 2014, ss.115-127.

TEZCAN, Mehmet," İran Armeniası (Pers-Armenia)", Tarihte Türkler ve Ermeniler (İlkçağ ve Ortaçağ), (Ed: Mehmet Metin Hülagü vd.), TTK. Yay., C.1, Ankara 2014, ss.149-182.

TÜRKMEN, İlhan, "Selçukluların Gayr-i Türk Unsurlara Uyguladığı Hoşgörü ve Adalet Politikası", Tarihte Türkler ve Ermeniler (Birlikte Yaşama Kültürü), (Ed: Mehmet Metin Hülagü vd.), TTK. Yay., C.3, Ankara 2014 ss.129-147.

YAĞCI, Zübeyde Güneş, “Osmanlı Devleti’nde İnşaat Sektöründe Ermeniler", Tarihte Türkler ve Ermeniler (Sosyo-Ekonomik Hayat), (Ed: Mehmet Metin Hülagü vd.), TTK. Yay., C.5, Ankara 2014, ss.97112. 